\title{
UJI LENTUR BALOK BETON BERTULANG BAJA RINGAN DENGAN SKEMA TULANGAN TUNGGAL
}

\author{
Christianto Credidi Septino Khala ${ }^{1)}$, Basyaruddin ${ }^{2)}$, \\ Muhammad Syahrizal Muslimin ${ }^{3)}$, Andina Prima Putri ${ }^{4)}$ \\ Jurusan Teknik Sipil dan Perencanaan, Institut Teknologi Kalimantan, Balikpapan \\ Email:chris.csk@lecturer.itk.ac.id ${ }^{1)}$,basyaruddin@lecturer.itk.ac.id ${ }^{2)}$, \\ 07161059@student.itk.ac.id ${ }^{3}$, andina@lecturer.itk.ac.id ${ }^{4)}$
}

DOI: http://dx.doi.org/10.29103/tj.v11i1.418

(Received: December 2020 / Revised: January 2021 / Accepted: January 2021)

\begin{abstract}
Abstrak
Dalam dunia konstruksi, balok beton bertulang menggunakan tulangan longitudinal agar dapat menahan tegangan tarik yang terjadi pada penampang beton tersebut dan tulangan longitudinal yang digunakan adalah baja tulangan (rebar reinforcement). Tegangan tarik yang dapat mencapai 420 Mpa merupakan alasan utama baja tulangan digunakan pada beton bertulang, namun, akibat perkembangan teknologi, terdapat material yang mempunyai tegangan tarik yang melebihi baja tulangan yaitu baja ringan. Baja ringan adalah baja canai dingin (light cold rolled) dengan kualitas tinggi yang bersifat ringan dan tipis, namun memiliki tegangan tarik yang melebihi baja tulangan biasa yaitu $550 \mathrm{Mpa}$, oleh karena itu, untuk mengetahui kapasitas lentur balok beton berbaja ringan maka dilakukan penelitian dengan memanfaatkan baja ringan sebagai tulangan longitudinal yang selanjutnya dilakukan uji lentur sesuai SNI-4431-2011. Baja canai dingin yang digunakan adalah baja ringan tipe $\mathrm{C}$ (C75x0.75) dengan 3 skema benda uji. Skema pertama yaitu dengan memanfaatkan baja ringan secara utuh sedangkan skema kedua dan ketiga adalah hanya dengan memanfaatkan badan dari baja ringan tersebut sehingga masing-masing skema memiliki rasio penulangan sebesar $0.47 \%, 0.28 \%$, dan $0.28 \%$. Selain itu, beton bertulang biasa dengan rasio $0.63 \%$ turut diuji sebagai pembanding (skema 4). Hasil uji lentur menunjukkan bahwa skema 1 menunjukkan kuat lentur terbesar dari skema lainnya yaitu sebesar 7.48 Mpa. Selanjutnya, meskipun skema kedua dan ketiga memiliki rasio penulangan yang sama skema kedua memiliki kuat lentur 0.24 Mpa lebih besar dari skema ketiga yang bernilai 5.76 Mpa. Akhirnya, beton dengan tulangan biasa dengan rasio terbesar memiliki kuat lentur sebesar 5.06 Mpa.
\end{abstract}

Kata kunci: Baja Ringan, Rasio Penulangan, Tulangan Longitudinal, Uji Lentur

\begin{abstract}
In the world of construction, reinforced concrete beams generally use longitudinal reinforcement to withstand the tensile stress that occurs in the concrete section and the longitudinal reinforcement used is rebar reinforcement. The tensile stress that can reach $420 \mathrm{Mpa}$ is the main reason reinforcing steel is used in reinforced concrete. However, due to technological developments, there is a material that has tensile stress that exceeds that of reinforcing steel, namely mild steel. Mild steel is light cold-rolled steel with high quality which is light and thin but has tensile stress that exceeds ordinary reinforcing steel, which is $550 \mathrm{Mpa}$. Therefore, to determine the flexural capacity of lightweight steel beams, research was carried out using mild steel as
\end{abstract}

Uji Lentur Balok Beton Bertulang Baja Ringan Dengan Skema Tulangan 171 Tunggal - Christianto Credidi Septino Khala, Basyaruddin, Muhammad Syahrizal Muslimin, Andina Prima Putri 


\begin{abstract}
longitudinal reinforcement, which was then carried out by bending tests according to SNI-4431-2011. Cold rolled steel used is mild steel type C (C75x0.75) with 3 specimen schemes. The first scheme is to make full use of mild steel, while the second and third schemes are only to utilize the body of the mild steel so that each scheme has a reinforcement ratio of $0.47 \%, 0.28 \%$, and $0.28 \%$. Also, ordinary reinforced concrete with a ratio of $0.63 \%$ was also tested for comparison (fourth scheme). The flexural test results show that scheme 1 shows the largest flexural strength of the other schemes, namely 7.48 Mpa. Furthermore, although the second and third schemes have the same reinforcement ratio, the second scheme has a bending strength of $0.24 \mathrm{MPa}$ which is greater than the third scheme which is $5.76 \mathrm{MPa}$. Finally, concrete with ordinary reinforcement with the largest ratio has a bending strength of 5.06 Mpa.
\end{abstract}

Keywords: Bending Test, longitudinal reinforcement, Mild Steel, Reinforcement Ratio

\title{
1. Latar Belakang
}

Beton merupakan material yang sering dijumpai pada pekerjaan kontruksi karena bahan penyusun beton mudah didapatkan, dan pada pengerjaanya beton dapat dibentuk sedemikian rupa. Salah satu jenis beton yang sering digunakan adalah beton bertulang dengan fungsi utama tulangan adalah menahan tegangan tarik yang terjadi. Beton bertulang merupakan beton yang ditulangi dengan luas dan jumlah tulangan tertentu untuk mendapatkan suatu elemen yang dapat bekerja sama dalam menahan gaya yang terjadi (Andrean, Sumajouw and Windah, 2015).

Menurut (W H.Mosley and J.H.Bungey, 1987) kekuatan tarik beton besarnya kurang lebih $10 \%$ kekuatan tekan. Oleh sebab itu hampir seluruh perencanaan kontruksi beton bertulang direncanakan dengan asumsi beton sama sekali tidak memikul gaya tarik. Gaya tarik sendiri direncanakan ditahan oleh baja tulangan. Salah satu penerapan beton bertulang yaitu sebagai balok. Balok beton bertulang umumnya diberi tulangan longitudinal dan tulangan sengkang. Tulangan longitudinal digunakan untuk menahan gaya lentur dan tulangan sengkang untuk menahan gaya geser yang terjadi. Balok merupakan salah satu elemen struktur yang ada pada setiap bangunan, termasuk pada bangunan gedung yang berfungsi sebagai pendukung plat, pengaku horizontal, dan sebagai bagian dari rangka struktur bangunan.

Secara umum, beton bertulang konvensional memiliki berat jenis sebesar $2400 \mathrm{~kg} / \mathrm{m}^{3}$ dengan kuat leleh maksimum baja tulangan yang digunakan sebagai tulangan lentur adalah sebesar $420 \mathrm{Mpa}$ (BjTS 420) (BSN 2847, 2019). Sejalan dengan perkembangan teknologi material, terdapat material lain yang memiliki kuat leleh/kuat tarik yang lebih besar dari pada baja tulangan biasa yaitu baja ringan. Baja ringan merupakan baja yang memiliki kuat tarik yang cukup tinggi dan memiliki sifat ringan dibandingkan dengan baja biasa karena memiliki penampang yang sangat tipis. Semakin berkembangnya dunia konstruksi bangunan penggunaan baja ringan dapat digunakan pada struktur sekunder hingga struktur utama. Konsep penerapan baja ringan pada struktur utama bangunan berupa inovasi yang berkaitan dengan konsep struktur tahan gempa. Penerapan baja ringan dalam dunia konstruksi dapat diterapkan pada kuda-kuda atap dan pada pelat lantai bangunan, yang perhitungan dan pelaksanaanya diatur dalam BSN 7971, 2013.

Baja ringan atau disebut juga sebagai baja canai dingin, memiliki kualitas tinggi yang bersifat ringan dan tipis, namun memiliki kekuatan struktur yang

Uji Lentur Balok Beton Bertulang Baja Ringan Dengan Skema Tulangan 172

Tunggal - Christianto Credidi Septino Khala, Basyaruddin, Muhammad Syahrizal Muslimin, Andina Prima Putri 
mendekati dengan baja tulangan konvensional. Berdasarkan Standar Nasional (BSN 4906, 2007), sifat mekanis baja ringan dengan mutu G550 memiliki kuat Tarik minimum $550 \mathrm{MPa}$ setara dengan baja konvensional mutu BjTS 550 yang memiliki kuat tarik minimum $687.5 \mathrm{MPa}$ dan kuat leleh minimum $550 \mathrm{MPa}$. Penggunaan baja ringan sebagai pengganti tulangan konvensional pada balok diharapkan dapat mengurangi beban struktural pada elemen balok namun tetap dapat menahan pembebanan diatasnya, yang kemudian dapat mengurangi dampak beban.

Atas dasar-dasar pertimbangan yang telah dijelaskan sebelumnya, penelitian tentang uji lentur balok beton bertulangan baja ringan dilakukan Sehingga diharapkan material baja ringan canai dingin dapat dijadikan alternatif tulangan beton sertavmemiliki kekuatan yang sama dengan beton bertulang

\section{Metode Penelitian}

Secara garis besar metode pengumpulan data serta pengujian yang dilakukan dalam penelitian ini dibagi menjadi beberapa tahap yaitu pengujian material penyusun beton, uji tekan beton dan yang terakhir adalah uji lentur beton bertulang baja ringan.

\subsection{Pengujian Material Penyusun Beton}

Penelitian yang dilakukan berupa pengujian material penyusun beton (agregat kasar dan agregat halus), pembuatan benda uji, pengujian karakteristik (slump, dan berat isi) beton. Seluruh pengujian dilakukan di Laboratorium Beton Program Studi Teknik Sipil, Jurusan Teknik Sipil dan Perencanaan, Institut Teknologi Kalimantan dimana tujuan dilakukan tahap ini adalah untuk mendapatkan data-data yang dapat dilihat pada Tabel 1 .

Tabel 1 Propertis material penyusun beton dan mix design

\begin{tabular}{llcc}
\hline No. & \multicolumn{1}{c}{ Uraian } & Nilai & Satuan \\
\hline 1. & Kuat tekan yang disyaratkan (Pada & 20 & $\mathrm{MPa}$ \\
\hline umur 28 hari) & Standar deviasi & 7 & - \\
\hline 3. & Kuat tekan rata-rata yang ditargetkan & 31,84 & $\mathrm{MPa}$ \\
\hline 4. & Jenis semen & Pasir alami & - \\
\hline 5. & Jenis agregat : - Halus & Batu pecah & - \\
\hline 6. & Faktor air-semen & 0,43 & - \\
\hline 7. & Faktor air-semen maksimum & 0,6 & - \\
\hline 8. & Slump & $10 \pm 2$ & $\mathrm{~cm}$ \\
\hline 9. & Ukuran agregat maksimum & 20 & $\mathrm{~mm}$ \\
\hline 10. & Kadar air bebas & 205 & $\mathrm{~mm}$ \\
\hline 11. & Kadar semen & 451 & $\mathrm{~kg} / \mathrm{m}^{3}$ \\
\hline 12. & Kadar semen maksimum & - & - \\
\hline 13. & Kadar semen minimum & 275 & $\mathrm{~kg} / \mathrm{m}^{3}$ \\
\hline 14. & Faktor air-semen yang disesuaikan & - & - \\
\hline 15. & Susunan butir agregat halus & Zona 4 & - \\
\hline 16. & Susunan butir agregat kasar & 30 & - \\
\hline 17. & Persentase kebutuhan agregat halus & & $\%$ \\
\hline & & Zona $20 \mathrm{~mm}$ & \\
\hline
\end{tabular}

Uji Lentur Balok Beton Bertulang Baja Ringan Dengan Skema Tulangan 173 Tunggal - Christianto Credidi Septino Khala, Basyaruddin, Muhammad Syahrizal Muslimin, Andina Prima Putri 


\begin{tabular}{clcc}
\hline No. & \multicolumn{1}{c}{ Uraian } & Nilai & Satuan \\
\hline 18. & Berat jenis relatif agregat & 2.77 & - \\
\hline 19. & Berat isi beton & 2435 & $\mathrm{~kg} / \mathrm{m}^{3}$ \\
\hline 20. & Kadar agregat gabungan & 1753 & $\mathrm{~kg} / \mathrm{m}^{3}$ \\
\hline 21. & Kadar agregat halus & 526 & $\mathrm{~kg} / \mathrm{m}^{3}$ \\
\hline 22. & Kadar agregat kasar & 1227 & $\mathrm{~kg} / \mathrm{m}^{3}$ \\
\hline & Proporsi campuran & & \\
- Semen & 477 & $\mathrm{~kg} / \mathrm{m}^{3}$ \\
23. & - Agregat halus & 526 & $\mathrm{~kg} / \mathrm{m}^{3}$ \\
- Agregat kasar & 1227 & $\mathrm{~kg} / \mathrm{m}^{3}$ \\
- Air & 205 & $\mathrm{~kg} / \mathrm{m}^{3}$ \\
\hline Koreksi proporsi campuran & & \\
(akibat kadar air dan penyerapan air) & & \\
24. Semen & 477 & $\mathrm{~kg} / \mathrm{m}^{3}$ \\
- Agregat halus & 528 & $\mathrm{~kg} / \mathrm{m}^{3}$ \\
- Agregat kasar & 1216 & $\mathrm{~kg} / \mathrm{m}^{3}$ \\
- Air & 196 & $\mathrm{~kg} / \mathrm{m}^{3}$ \\
\hline Koreksi proporsi campuran & & \\
(dikali safety factor =1.2) & & \\
- Semen & 572 & $\mathrm{~kg} / \mathrm{m}^{3}$ \\
- Agregat halus & 634 & $\mathrm{~kg} / \mathrm{m}^{3}$ \\
- Agregat kasar & 1460 & $\mathrm{~kg} / \mathrm{m}^{3}$ \\
- Air & 235 & $\mathrm{~kg} / \mathrm{m}^{3}$ \\
\hline Perbandingan kadar material beton & & \\
- Semen & 1,00 & \\
26. Agregat halus & 1,10 & \\
- Agregat kasar & 2,57 & \\
- Air & 0,43 & \\
\hline & & & \\
\hline & & & \\
\hline
\end{tabular}

Adapun standar pengujian yang digunakan dalam tahap ini adalah BSN 1971, 2011 tentang cara uji kadar air total agregat dengan pengeringan, BSN 1970, 2008 tentang cara uji berat jenis dan penyerapan air agregat halus, BSN 1968, 1990, tentang metode pengujian analisis saringan agregat halus dan kasar dan BSN 2834, 2000 tentang tata cara pembuatan rencana campuran beton normal.

\subsection{Pengujian Kuat Tekan Beton}

Pengujian kuat tekan beton mengacu pada BSN 1974, 2011 tentang cara uji kuat tekan beton dengan benda uji silinder dan dengan menggunakan benda uji beton berbentuk silinder dengan ukuran diameter $15 \mathrm{~cm}$ dan tinggi $30 \mathrm{~cm}$. Pengujian kuat tekan ini dilakukan pada saat umur benda uji beton 28 hari dengan jumlah benda uji sebanyak 3 buah benda uji. Tujuan dari pengujian kuat tekan ini yaitu untuk mengetahui kekuatan tekan beton dari hasil mix design atau campuran yang telah dibuat sesuai dengan yang telah direncanakan.

\subsection{Pengujian Kuat Lentur Beton}

Uji Kuat lentur dilakukan berdasarkan peraturan BSN 4431, 2011 di mana penampang beton bertulang dibebani lentur murni. Asumsi yang digunakan dalam menganalisis beton bertulang yang diberi beban lentur adalah:

Uji Lentur Balok Beton Bertulang Baja Ringan Dengan Skema Tulangan Tunggal - Christianto Credidi Septino Khala, Basyaruddin, Muhammad Syahrizal Muslimin, Andina Prima Putri 
1) Beton tidak dapat menerima gaya tarik karena beton tidak mempunyai kekuatan Tarik.

2) Perubahan bentuk berupa pertambahan panjang dan perpendekkan (regangan tarik dan tekan) pada serat-serat penampang, berbanding lurus dengan jarak tiap serat ke sumbu netral.

3) Hubungan antara tegangan dan regangan baja dapat dinyatakan secara skematis.

4) Hubungan antara tegangan dan regangan beton dapat dinyatakan secara skematis.

Untuk pengujian dimana bidang patah terletak di daerah pusat (daerah $1 / 3$ jarak titik perletakan bagian tengah), maka kuat lentur beton dihitung menurut persamaan 1.

$$
\sigma_{I}=\frac{P . L}{b \cdot h^{2}}
$$

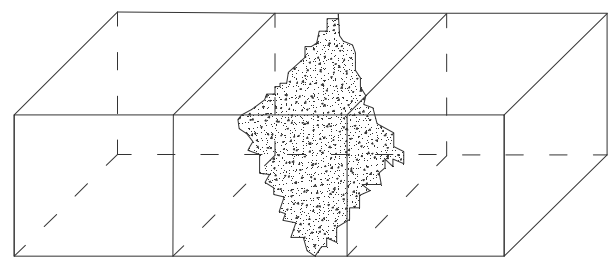

Gambar 1 Balok dengan patahan 1/3 bentang dari jarak titik perletakan bagian tengah (Sumber: BSN 4431, 2011)

Untuk pengujian di mana patahnya benda uji ada di luar pusat (daerah 1/3 jarak titik perletakan bagian tengah), dan jarak antara titik pusat dan titik patah kurang dari 5\% dari jarak antara titik perletakan maka kuat lentur beton dihitung menurut persamaan 2.

$$
\sigma_{I}=\frac{P \cdot a}{b \cdot h^{2}}
$$

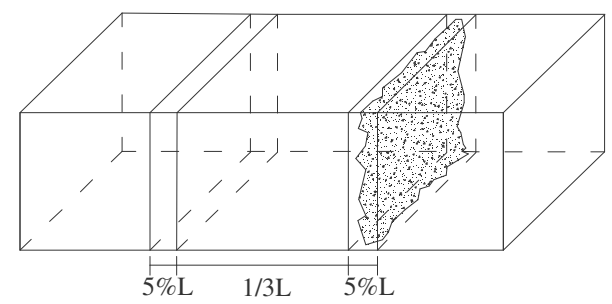

Gambar 2 Balok dengan patahan 1/3 bentang tengah dan garis patah pada $<5 \%$ dari bentang (Sumber: BSN 4431, 2011)

di mana:

$\sigma_{I} \quad=$ Kuat lentur benda uji $(\mathrm{MPa})$

$P \quad=$ Beban tertinggi yang terbaca pada mesin uji (ton)

$L \quad=$ Jarak antara dua garis perletakan $(\mathrm{mm})$

$b \quad=$ Lebar tampang lintang patah arah horizontal $(\mathrm{mm})$

$h=$ Lebar tampang lintang patah arah vertikal $(\mathrm{mm})$

$a \quad=$ Jarak rata-rata tampang litang patah dan tumpuan luar yang diukur pada 4 tempat pada sudut dari bentang ( $\mathrm{mm})$

Uji Lentur Balok Beton Bertulang Baja Ringan Dengan Skema Tulangan 
Untuk benda uji yang patahnya di luar pusat (daerah 1/3 jarak titik perletakan bagian tengah) dan jarak antar titik pembebanan dan titik patah lebih dari $5 \%$ bentang, hasil pengujian tidak digunakan.

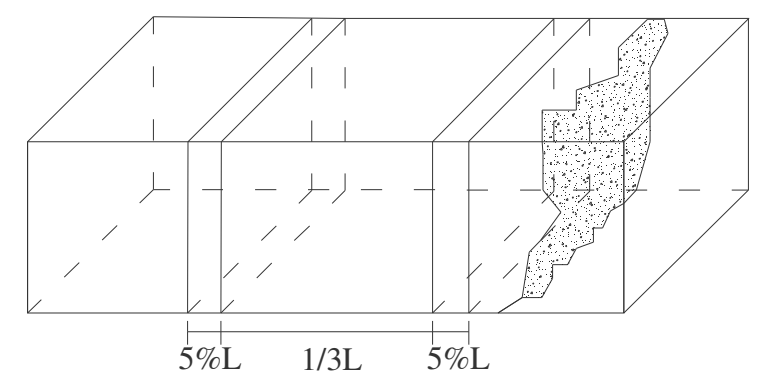

Gambar 3 Balok dengan patahan di luar 1/3 bentang tengah dan garis patah pada $>5 \%$ dari bentang (Sumber: BSN 4431, 2011)

Besaran tegangan akibat lenturan dapat ditulis dengan persamaan sebagai berikut.

$$
\sigma=\frac{M \times y}{I}
$$

di mana:

$\sigma=$ Tegangan Lentur

$M=$ Momen Lentur

$y \quad=$ Jarak tegak lurus garis netral ke titik tinjau

$I \quad=$ Momen Inersia

Adapun skema pengujian kuat lentur balok beton bertulangan pilinan bambu yang disajikan pada gambar 4 .

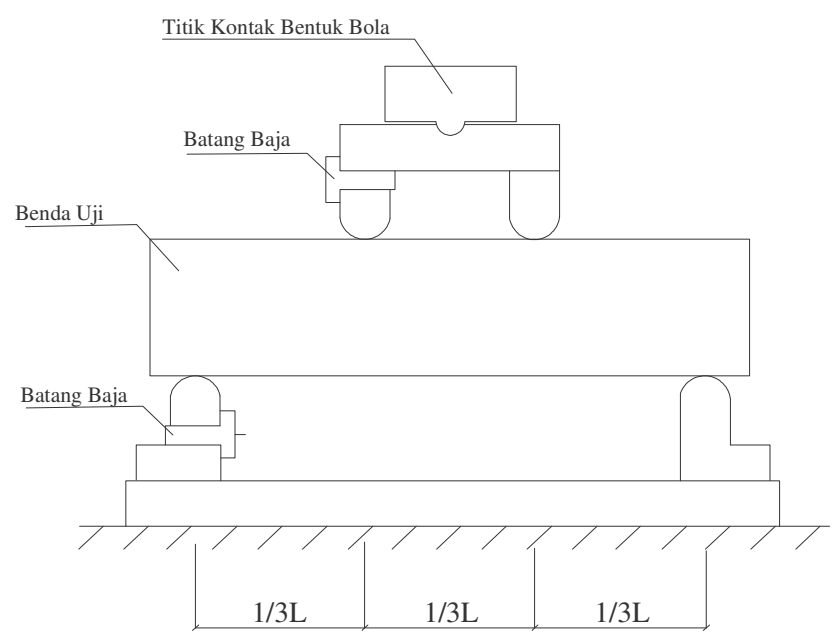

Gambar 4 Skema pengujian kuat lentur balok beton

\section{Hasil dan Pembahasan}

\subsection{Kuat Tekan Beton}

Hasil kuat tekan beton berdasarkan campuran yang diperoleh dalam ready mix dapat dilihat pada Tabel 2.

Uji Lentur Balok Beton Bertulang Baja Ringan Dengan Skema Tulangan Tunggal - Christianto Credidi Septino Khala, Basyaruddin, Muhammad Syahrizal Muslimin, Andina Prima Putri 
Tabel 2 Data hasil uji tekan

\begin{tabular}{ccccccc}
\hline No & Benda Uji & $\begin{array}{c}\text { Umur Luas Permukaan } \\
(\text { Hari) }\end{array}$ & $\boldsymbol{P}(\mathbf{k N})$ & $\begin{array}{c}\text { Faktor } \\
\text { Koreksi }\end{array}$ & $\begin{array}{c}\boldsymbol{f} \boldsymbol{c} \boldsymbol{c} \\
(\mathbf{M P a})\end{array}$ \\
\hline 1 & Beton 1 & 28 & 176.63 & 490 & 1,00 & 28.29 \\
\hline 2 & Beton 2 & 28 & 176.63 & 420 & 1,00 & 24.25 \\
\hline 3 & Beton 3 & 28 & 176.63 & 470 & 1,00 & 27.13 \\
\hline \multicolumn{7}{r}{ Rata-rata } \\
\hline
\end{tabular}

Berdasarkan tabel di atas, dihasilkan nilai kuat tekan rata-rata sebesar 26.56 $\mathrm{MPa}$, dimana nilai kuat tekan tersebut melebihi nilai kuat tekan yang rencanakan yakni $20 \mathrm{MPa}$. Dari tabel di atas, dapat disimpulkan bahwa hasil perhitungan mix design yang telah dilakukan sesuai dengan yang telah ditargetkan dan dapat digunakan untuk pembuat benda uji balok beton bertulang baja ringan.

\subsection{Tegangan lentur balok beton berbaja ringan}

Pengujian kuat lentur beton dilakukan untuk mengetahui nilai beban maksimum yang dihasilkan dan juga untuk mengetahui keretakan yang terjadi berdasarkan jenis keruntuhan pada balok. Pengujian yang dilakukan menggunakan benda uji dengan dimensi $15 \times 15 \times 60 \mathrm{~cm}$ dengan variasi balok tulangan konvensional (skema 4), tulangan baja ringan kanal c (skema 1), tulangan baja ringan kanal c tanpa sayap (skema 2), tulangan baja ringan kanal c tanpa sayap terpisah (skema 3). Adapun bentuk benda uji disajikan pada gambar $5,6,7$, dan 8 .

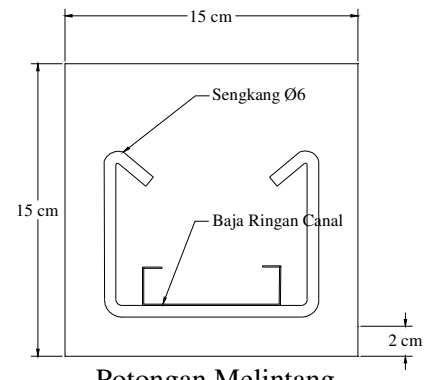

Potongan Melintang

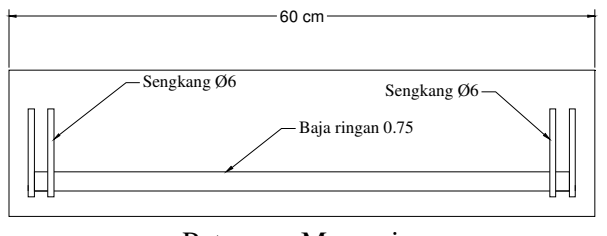

Potongan Memanjang

Gambar 5 Tulangan baja ringan canal C (skema 1)

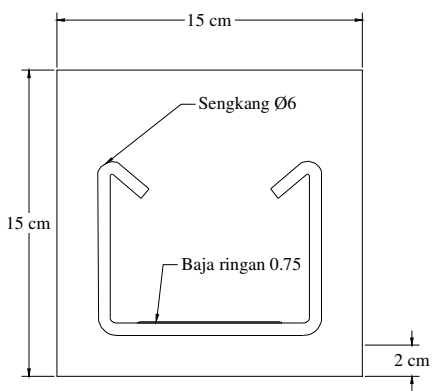

Potongan Melintang

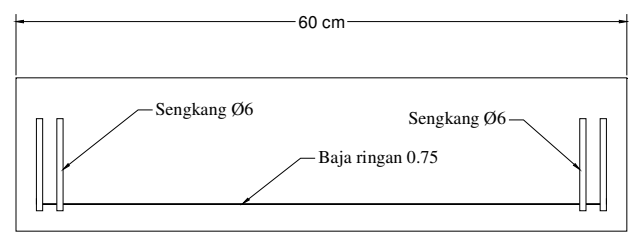

Potongan Memanjang

Gambar 6 Tulangan baja ringan kanal c tanpa sayap (skema 2)

Uji Lentur Balok Beton Bertulang Baja Ringan Dengan Skema Tulangan Tunggal - Christianto Credidi Septino Khala, Basyaruddin, Muhammad Syahrizal Muslimin, Andina Prima Putri 


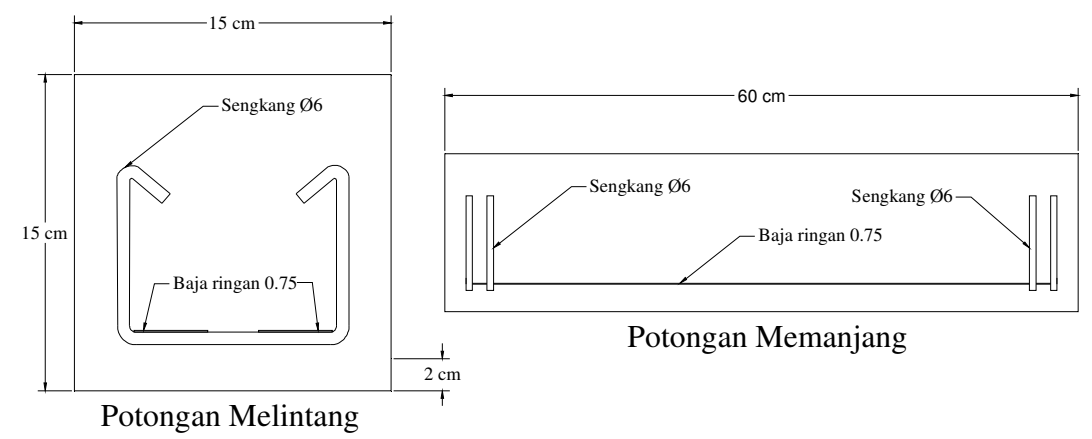

Gambar 7 Tulangan baja ringan kanal c tanpa sayap terpisah (skema 3)

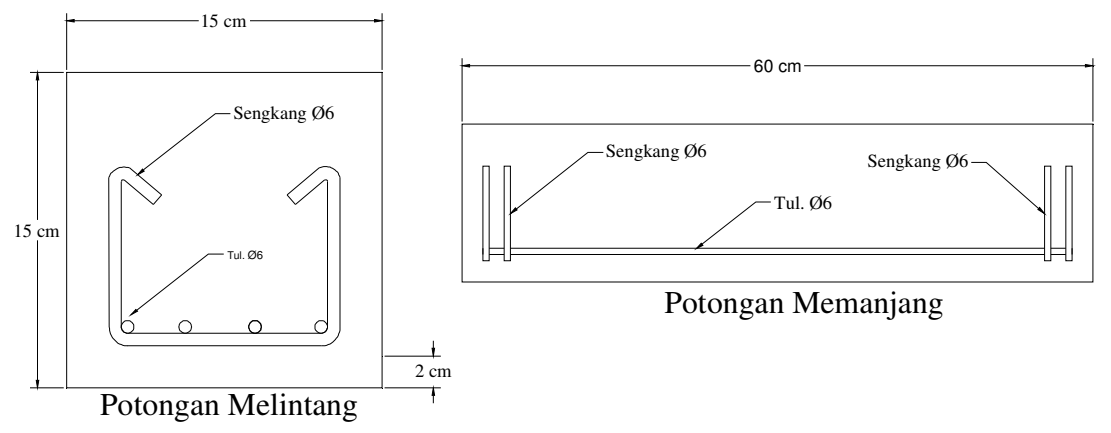

Gambar 8 Balok dengan tulangan konvensional (skema 4)

Hasil uji lentur untuk masing-masing benda uji dapat dilihat pada Tabel 3.

Tabel 3 Nilai kuat lentur dan beban maksimum

\begin{tabular}{cccccc}
\hline Rasio & Benda Uji & $\begin{array}{c}\text { Beban } \\
\text { Maksimum } \\
(\mathbf{K N})\end{array}$ & $\begin{array}{c}\text { Beban } \\
\text { Maksimum } \\
\text { Rata-rata } \\
(\mathbf{K N})\end{array}$ & $\begin{array}{c}\text { Kuat } \\
\text { Lentur } \\
(\mathbf{M P a})\end{array}$ & $\begin{array}{c}\text { Kuat Lentur } \\
\text { Rata-rata } \\
(\mathbf{M P a})\end{array}$ \\
\hline \multirow{2}{*}{$0.469 \%$} & Skema I(1) & 53 & & 8.009 & \\
& Skema I(2) & 55.50 & 49.5 & 8.387 & 7.480 \\
& Skema I(3) & 40 & & 6.044 & \\
\hline \multirow{2}{*}{$0.283 \%$} & Skema II(1) & 43 & & 6.498 & \\
& Skema II(2) & 41 & 40.167 & 6.196 & 6.070 \\
& Skema II(3) & 36.5 & & 5.156 & \\
\hline \multirow{2}{*}{$0.283 \%$} & Skema III(1) & 32.5 & & 4.911 & \\
& Skema III(2) & 41 & 38.167 & 6.196 & 5.767 \\
& Skema III(3) & 41 & & 6.196 & \\
\hline \multirow{2}{*}{$0.628 \%$} & Skema IV(1) & 47.5 & & 7.178 & \\
& Skema IV(2) & 18 & 33.5 & 2.720 & 5.062 \\
& Skema IV(3) & 35 & & 5.289 & \\
\hline
\end{tabular}

\subsection{Perbandingan dengan penelitian sebelumnya}

Pada tahun 2008, Wigroho et al., telah mencoba memanfaatkan profil C tunggal dengan ukuran tingi $93.2 \mathrm{~mm}$, lebar $34.9 \mathrm{~mm}$, tinggi bibir $8.5 \mathrm{~mm}$ dan tebal $2.06 \mathrm{~mm}$ diberi perkuatan baja tulangan diameter $6 \mathrm{~mm}$ yang dipasang

Uji Lentur Balok Beton Bertulang Baja Ringan Dengan Skema Tulangan 178 Tunggal - Christianto Credidi Septino Khala, Basyaruddin, Muhammad Syahrizal Muslimin, Andina Prima Putri 
vertikal dengan cara dilas pada dua sayap yang terbuka dan juga diberi cor beton dengan $f_{c}=20 \mathrm{Mpa}$. Kuat lentur Balok profil $\mathrm{C}$ yang dicor ditentukan dengan cara melakukan uji lentur balok dengan panjang $1.8 \mathrm{~m}$ dan hasil pengujian menunjukkan bahwa profil $\mathrm{C}$ yang dicor mempunyai kuat lentur sebesar 53.26 Mpa sedangkan balok profil $\mathrm{C}$ yang tidak dicor menunjukkan nilai kuat lentur sebesar 21.64 Mpa. Hasil kuat lentur ini tentu saja sangat berbeda jauh dengan hasil penelitian yang telah disajikan pada tabel 3 karena profil $\mathrm{C}$ yang digunakan lebih kecil yaitu baja ringan tipe $\mathrm{C}(\mathrm{C} 75 \mathrm{x} 0.75)$. Namun dari hasil penelitian ini dapat disimpulkan bahwa profil $\mathrm{C}$ yang dicor dapat meningkatkan nilai kuat lentur. (Yohanes, 2019) turut serta dalam menganalisa pemanfaatan beton berbaja ringan pada elemen kolom dan memperoleh beban maksimum yang dapat ditahan oleh kolom beton berbaja ringan adalah $264.28 \mathrm{kN}$. Penelitan lain yang memanfaatkan material komposit beton dan baja ringan adalah penelitan yang dilakukan oleh Suandi, 2020. Suandi mengatakan bahwa kuat lentur rata-rata pada sampel beton berbaja ringan yaitu $11.81 \mathrm{Mpa}$ dan beton tulangan biasa adalah 9.993 Mpa, sehingga dengan hasil yang telah didapat ini maka baja ringan kanal C dapat digunakan sebagai alternatif pengganti pada tulangan baja tulangan kususnya pada balok dengan dimensi $15 \times 15 \mathrm{~cm}$.

\section{Kesimpulan dan Saran}

\subsection{Kesimpulan}

Hasil uji lentur memperlihatkan bahwa skema 1 (pemanfaatan profil C secara keseluruhan sebagai pengganti tulangan longitudinal) menunjukkan kuat lentur terbesar dari skema lainnya yaitu sebesar 7.48 Mpa. Selanjutnya, meskipun skema kedua dan ketiga memiliki rasio penulangan yang sama skema kedua memiliki kuat lentur 0.24 Mpa lebih besar dari skema ketiga yang bernilai 5.76 Mpa. Akhirnya, beton dengan tulangan biasa dengan rasio terbesar memiliki kuat lentur sebesar 5.06 Mpa. Berdasarkan hasil pengujian tersebut dapat disimpulkan bahwa beton berbaja ringan merupakan balok beton yang lebih baik dalam menahan lentur dibandingkan dengan balok beton bertulang biasa.

\subsection{Saran}

Sebagai pertimbangan, penelitian ini menggunakan skema tulangan tunggal. Oleh karena itu, pada penelitian selanjutnya sangat diharapkan untuk menggunakan skema tulangan ganda sehingga kuat lentur yang diperoleh jauh lebih besar dan potensi pemanfaatan baja ringan sebagai tulangan pada beton bertulang dapat dimaksimalkan.

\section{Ucapan Terima Kasih}

Dalam penelitian ini peneliti sangat berterima kasih kepada kementerian ristekdikti yang telah menyalurkan dananya sehingga peneliti dapat menyelesaikan topik penelitian ini. Selain itu, terima kasih pula kepada seluruh laboran teknik sipil ITK - Balikpapan, Poltekba - Balikpapan dan Polnes Samarinda yang telah membantu dalam proses pengujian benda uji.

Uji Lentur Balok Beton Bertulang Baja Ringan Dengan Skema Tulangan 


\section{Daftar Kepustakaan}

Andrean, S., Sumajouw, M. D. J. and Windah, R. S. (2015) 'Pengujian Kuat Lentur Balok Beton Bertulang Dengan Variasi Ratio Tulangan Tarik', Jurnal Sipil Statik Maret, 3(3), pp. 175-182.

BSN 1968 (1990) 'SNI 03-1968-1990 Metode Pengujian Tentang Analisis Saringan Agregat Halus dan Kasar', Badan Standar Nasional Indonesia.

BSN 1970 (2008) 'SNI 1970-2008 Cara Uji Berat Jenis dan Penyerapan Air Agregat Halus', Badan Standar Nasional Indonesia.

BSN 1971 (2011) 'SNI 1971-2011 Cara Uji Kadar Air Total Agregat dengan Pengeringan', Badan Standar Nasional Indonesia.

BSN 1974 (2011) 'SNI 1974-2011 Cara Uji Kuat Tekan Beton dengan Benda Uji Silinder', Badan Standardisasi Nasional Indonesia.

BSN 2834 (2000) 'SNI 03-2834-2000 Tata cara pembuatan rencana campuran beton normal', Badan Standar Nasional Indonesia.

BSN 2847 (2019) 'SNI 03-2847-2019 Persyaratan Beton Struktural Untuk Bangunan Gedung Dan Penjelasan Sebagai Revisi Dari Standar Nasional Indonesia 2847 $\square$ : 2013', Badan Standarisasi Nasional.

BSN 4431 (2011) 'SNI 4431-2011 Cara Uji Kuat Lentur Beton Normal Dengan Dua Titik Pembebanan', Badan Standar Nasional Indonesia.

BSN 4906 (2007) 'SNI 4906-2007 Baja lembaran dan gulungan lapis paduan aluminium - seng ( Bj . LAS )', Badan Standar Nasional Indonesia.

BSN 7971 (2013) 'SNI 7971-2013 Struktur Baja Canai Dingin', Badan Standar Nasional Indonesia.

Suandi, A. (2020) 'Analisa Kuat Lentur Balok Beton Bertulang Dengan Menggunakan Profil Baja Ringan Tulangan'. Universitas Muhammadiyah Metro.

W H.Mosley and J.H.Bungey (1987) Reinforced Concrete Design, Macmillan Education Ltd.

Wigroho, H. Y. et al. (2008) 'Kuat Lentur Profil C Tunggal Dengan Perkuatan Tulangan Vertikal Dan Cor Beton Pengisi', Jurnal Teknik Sipil Universitas Atma Jaya Yogyakarta, 8(3), pp. 264-277.

Yohanes, C. I. S. (2019) 'Analisis Perbandingan Kuat Tekan Dan Kuat Lentur Antara Kolom Beton Bertulang Besi Polos Dengan Kolom Beton Bertulang Baja Ringan Untuk Rumah Sederhana'. Universitas Widya Dharma.

Copyright (c) Basyaruddin - -, Christianto Credidi Septino Khala,

Muhammad Syahrizal Muslimin, Andina Prima Putri

Uji Lentur Balok Beton Bertulang Baja Ringan Dengan Skema Tulangan 180

Tunggal - Christianto Credidi Septino Khala, Basyaruddin, Muhammad Syahrizal Muslimin, Andina Prima Putri 